Article

\title{
Undoped and $\mathrm{Eu}^{3+}$ Doped Magnesium-Aluminium Layered Double Hydroxides: Peculiarities of Intercalation of Organic Anions and Investigation of Luminescence Properties
}

\author{
Aurelija Smalenskaite ${ }^{1, *}$, Lina Pavasaryte ${ }^{2,3}$, Thomas C. K. Yang ${ }^{2,3}$ and Aivaras Kareiva ${ }^{1}$ \\ 1 Department of Inorganic Chemistry, Vilnius University, Naugarduko 24, LT 03225 Vilnius, Lithuania; \\ aivaras.kareiva@chgf.vu.lt \\ 2 Department of Chemical Engineering and Biotechnology, National Taipei University of Technology, 1, Sec. 3, \\ Chung-Hsiao E. Road, Taipei 106, Taiwan; lina.pavasaryte@gmail.com (L.P.); ckyang@ntut.edu.tw (T.C.K.Y.) \\ 3 Center for Precision Analysis and Materials Research, National Taipei University of Technology, 1, Sec. 3, \\ Zhongxiao E. Rd., Taipei 10608, Taiwan \\ * Correspondence: aurelija.smalenskaite@chf.vu.lt
}

Received: 11 January 2019; Accepted: 28 February 2019; Published: 4 March 2019

check for updates

\begin{abstract}
The $\mathrm{Mg}_{3} / \mathrm{Al}$ and $\mathrm{Mg}_{3} / \mathrm{Al}_{0.99} \mathrm{Eu}_{0.01}$ layered double hydroxides (LDHs) were fabricated using a sol-gel chemistry approach and intercalated with different anions through ion exchange procedure. The influence of the origin of organic anion (oxalate, laurate, malonate, succinate, tartrate, benzoate, 1,3,5-benzentricarboxylate (BTC), 4-methylbenzoate (MB), 4-dimethylaminobenzoate (DMB) and 4-biphenylacetonate (BPhAc)) on the evolution of the chemical composition of the inorganic-organic LDHs system has been investigated. The obtained results indicated that the type and arrangement of organic guests between layers of the LDHs influence $\mathrm{Eu}^{3+}$ luminescence in the synthesized different hybrid inorganic-organic matrixes. For the characterization of synthesis products X-ray diffraction (XRD) analysis, infrared (FTIR) spectroscopy, fluorescence spectroscopy (FLS), and scanning electron microscopy (SEM), were used.
\end{abstract}

Keywords: LDHs; Eu doping effect; intercalation of organic species; size effect; luminescence

\section{Introduction}

A general chemical formula of layered double hydroxides (LDHs) is $\left[\mathrm{M}^{2+}{ }_{1-x}\right.$ $\left.\mathrm{M}^{3+}{ }_{x}(\mathrm{OH})_{2}\right]^{x+}\left(\mathrm{A}^{y-}\right)_{x / y} \cdot z \mathrm{H}_{2} \mathrm{O}$, here $\mathrm{M}^{2+}$ and $\mathrm{M}^{3+}$ are divalent and trivalent cations forming layered structure, respectively, and $\mathrm{A}^{y-}$ is anion occupying interlayer space [1]. LDHs show hexagonal crystal structure that depends on different parameters of the intercalated species. Intercalation of different anions in LDH is a challenging topic because the anion-exchange could be performed mostly, when the introduced anion has higher affinity with the LDH layer than the host anion. Usually, the anions with small size and high charge density are used for such investigations. Nevertheless, the low-charge large organic anions could also be introduced to the LDH structure [2]. The possibility to substitute of monovalent anions in the $\mathrm{Mg} / \mathrm{Al} \mathrm{LDH}$ could be expressed by following order $\mathrm{OH}^{-}>\mathrm{F}^{-}>\mathrm{Cl}^{-}>\mathrm{Br}^{-}>\mathrm{NO}^{3-}$. More selective are anions with higher charge $\mathrm{CO}_{3}{ }^{2-}>\mathrm{SO}_{4}{ }^{2-}[3]$. The anion-exchange selectivity is usually related to the guest orientation. Two orientations are observed for the organic anion within the gallery either vertical perpendicular to the layers or horizontal. Whether a vertical or horizontal orientation exists, depends upon the charge on the layers and the degree of hydration of the sample. Moreover, the water molecules stabilize the LDH structure via formation of a hydrogen bond [4-6]. The organic anions can create negative charge 
in the LDH particles, which can be associated to the micellization or formation of self-assembly of exchanged or adsorbed organic anions on the LDH surface [7]. Furthermore, interaction between LDHs carbonate and carboxylate-containing substances is an important aspect of the high affinity of these types of anions to the LDH surface. The adsorption of monovalent anions on the positively charged surface can proceed differently, which can be classified by the indirect Hofmeister series of the ions. Deviation from the series of the ions was observed only for the $\mathrm{HCO}_{3}{ }^{-}$ions due to pronounced very high affinity to the LDH materials. Multivalent anions exhibit also high affinity to the LDH surfaces neutralizing the charge of the surface or even making it reversal at higher concentrations. This feature is more pronounced for anions with higher negative charge and platelets of significant negative charge could be formed. These results allow one to design LDH-based ion-exchange systems for different applications [8-10]. Besides, LDH intercalated with amino, ethylenediaminetetraacetic, diethylenetriaminepentaacetic, citric and malic acids could be used as adsorbents to remove toxic cationic and anionic species from aqueous media [11]. Moreover, LDHs intercalated with succinic acid and lauric acid were used as lubricant additives [12].

In recent years, inorganic-organic hybrid luminescence materials have been widely investigated due to the novel properties to form stable compounds with lanthanides based on unique anion exchange ability in the interlayer space of LDH. New photoluminescence materials when LDHs were doped with rare-earth (RE) have been synthesized $[13,14]$. These multifunctional materials are useful in many fields such as medicine, photochemistry, catalysis, environmental applications $[15,16]$. However, these LDHs show limitation due to the low intensity of emission which is caused by direct coordination of water molecules and hydroxyl groups to the RE centre in the layer. For the hybrid RE-organic LDH materials, intercalation of guest organic anions in the interlayer galleries influences the luminescence properties dramatically. For example, the enhanced green luminescence for $\mathrm{Tb}^{3+}$ by terephthalate anions in Tb-doped LDH was observed [17]. It was determined the possible energy transfer from the excited state of the introduced anion to $\mathrm{Tb}^{3+}$ active centres. The organic anions or neutral molecules should be chemically stable and have good solubility, significant mobility and capability to form amorphous layers [18]. The organic groups which have different donor-acceptor capabilities, different size and different lability are introduced into the LDHs host position. In the previous reports, the luminescence properties of $\mathrm{Eu}^{3+}$-doped LDHs intercalated by certain organic compounds, such as naphtalene-1,5-sulfonate, naphtalene-2,6-dicarboxylate [19] citrate, glutamate, picolinate, ethylenediaminetetraacetate [20], and many other compounds [21-24] have been investigated and discussed.

The goal of the present study was to investigate the luminescence properties of the $\mathrm{Eu}^{3+}$ doped LDHs containing organic anions. The influence of the origin of organic anion (oxalate, laurate, malonate, succinate, tartrate, benzoate, 1,3,5-benzentricarboxylate (BTC), 4-methylbenzoate (MB), 4-dimethylaminobenzoate (DMB) and 4-biphenylacetonate (BPhAc)) on the evolution of the chemical composition of the inorganic-organic LDHs system has been investigated.

\section{Experimental}

\subsection{Synthesis of $\mathrm{LDHs}$}

The $\mathrm{Mg}_{3} / \mathrm{Al}$ and $\mathrm{Mg}_{3} / \mathrm{Al}_{0.99} \mathrm{Eu}_{0.01} \mathrm{LDH}$ specimens were prepared by sol-gel technique using metal nitrates $\mathrm{Mg}\left(\mathrm{NO}_{3}\right)_{2} \cdot 6 \mathrm{H}_{2} \mathrm{O}, \mathrm{Al}\left(\mathrm{NO}_{3}\right)_{3} \cdot 9 \mathrm{H}_{2} \mathrm{O}$ and $\mathrm{Eu}\left(\mathrm{NO}_{3}\right)_{3} \cdot 6 \mathrm{H}_{2} \mathrm{O}$, dissolved in $50 \mathrm{~mL}$ of deionized water as starting materials. To the obtained mixture, the $0.2 \mathrm{M}$ solution of citric acid was added. The resulted solution was additionally stirred for $1 \mathrm{~h}$ at $80^{\circ} \mathrm{C}$. Finally, $2 \mathrm{~mL}$ of ethylene glycol was added with continued stirring at $150^{\circ} \mathrm{C}$. During the evaporation of solvent, the transformations from sol to the gel occurred. The synthesized precursor gel was dried at $105^{\circ} \mathrm{C}$ for $24 \mathrm{~h}$ and was used for the synthesis of $\mathrm{LDHs}$. The $\mathrm{Mg}_{3} / \mathrm{Al}$ and $\mathrm{Mg}_{3} / \mathrm{Al}_{0.99} \mathrm{Eu}_{0.01} \mathrm{LDHs}$ were fabricated by reconstruction of mixed-metal oxides (MMO) in deionized water at $80^{\circ} \mathrm{C}$ for $6 \mathrm{~h}$, The MMO were formed during annealing the gels at $650{ }^{\circ} \mathrm{C}$ for $4 \mathrm{~h}$. 


\subsection{Intercalation of $\mathrm{Mg}_{3} / \mathrm{Al}$ and $\mathrm{Mg}_{3} / \mathrm{Al}_{0.99} \mathrm{Eu}_{0.01} \mathrm{LDHs}$ with Organic Anions}

$\mathrm{Mg}_{3} / \mathrm{Al}$ or $\mathrm{Mg}_{3} / \mathrm{Al}_{0.99} \mathrm{Eu}_{0.01}$ benzoate, oxalate, laurate, malonate, succinate, tartrate, 1,3,5-benzentricarboxylate (BTC), 4-methylbenzoate (MB), 4-dimethylaminobenzoate (DMB) and 4-biphenylacetonate (BPhAc) were synthesized using anion exchange technique. For this, $2 \mathrm{mmol}$ of $\mathrm{Mg}_{3} / \mathrm{Al}$ or $\mathrm{Mg}_{3} / \mathrm{Al}_{0.99} \mathrm{Eu}_{0.01}$ was immersed in the solution of disodium/sodium organic compounds with 1.5 molar excess amounts in comparison with LDHs. Next, the solution was stirred at room temperature for $24 \mathrm{~h}$. After filtration and washing with deionized water and acetone, the synthesis product was dried at $40^{\circ} \mathrm{C}$ for $12 \mathrm{~h}$.

\subsection{Characterization}

X-ray diffraction analysis (XRD, Rigaku Mini Flex, Rigaku, The Woodlands, TX, USA) of synthesized compounds were performed with MiniFlex II diffractometer (Rigaku) using a primary beam Cu K $\alpha$ radiation $(\lambda=1.541838 \AA)$. The $2 \theta$ angle of the diffractometer was gradated from 8 to $80^{\circ}$ in steps of $0.02^{\circ}$, with the measuring time of $0.4 \mathrm{~s}$ per step. Fourier-transform infrared spectroscopy (FT-IR) spectra were recorded using Bruker-Alpha FT-IR spectrometer (Bruker, Ettlingen, Germany) in the range of $4000-400 \mathrm{~cm}^{-1}$. The luminescent properties were investigated using Edinburg Instruments FLS 980 spectrometer (Edinburgh Instruments, Kirkton Campus, UK). The surface morphological features were characterized using a scanning electron microscope (SEM, Hitachi, Tokyo, Japan) Hitachi SU-70. The particle and anion dimension sizes were calculated using the ImageJ and Avogadro programmes (Jolla, CA, USA). The amount of carbonate in the synthesized samples was calculated from the $\mathrm{M}^{\mathrm{II}} / \mathrm{M}^{\mathrm{III}}$ atomic ratios, assuming that carbonate is the only charge balancing interlayer anion. The water content in the formula was determined from the results of TG analyses. The chemical composition was defined to be $\left[\mathrm{Mg}_{0.75} \mathrm{Al}_{0.25}(\mathrm{OH})_{2}\right]\left(\mathrm{CO}_{3}\right)_{0.125} \cdot 4 \mathrm{H}_{2} \mathrm{O}$.

\section{Results and Discussion}

It is reported [3] that $\mathrm{LDH}$ containing not only nitrates or chlorides, but also $\mathrm{CO}_{3}{ }^{2-}$ could be used for intercalation of other inorganic anions. Free $\mathrm{CO}_{3}{ }^{2-}$ and the $\mathrm{NO}_{3}{ }^{-}$anions show similar symmetry, however, behave differently as interlayer anions in $\mathrm{LDHs}$ structure. The $\mathrm{CO}_{3}{ }^{2-}$ is orientated parallel to the hydroxide layers. It can easily interact with hydroxyl groups of hydroxide layers by forming hydrogen bonds [25]. The $\mathrm{NO}_{3}{ }^{-}$has molecular plane tilted orientation, which makes disorder of the 3R rhombohedral symmetry [26] within a hexagonal unit cell of LDH crystal structure. Previously, the LDHs were obtained using the anion-exchanged method showing that values of basal spacing $c$ increased significantly in comparison with starting carbonate containing LDH [11]. The parameter $c$ depends on the size, charge and orientation of the intercalated species.

In this work, the intercalated organic anions, such as short-long carbon chains (oxalate, laurate, malonate, succinate, tartrate) and benzoic (benzoate, 1,3,5-benzentricarboxylate, 4-methylbenzoate, 4-dimethylaminobenzoate and 4-biphenylacetonate) carboxyl acid groups could be arranged by anions size in the interlayer and by the charge to compensate the hydroxide layer. In the XRD patterns of the LDH phases obtained by the anion exchanged reactions the diffraction peaks were shifted to the lower values of $2 \theta$ angle proving that values of the basal spacing $c$ increased. The positions of diffraction peaks (003) of $\mathrm{LDHs}$ intercalated with short-long chains $\left(\mathrm{Mg}_{3} / \mathrm{Al}\right.$-succinate, $\mathrm{Mg}_{3} / \mathrm{Al}$-malonate, $\mathrm{Mg}_{3} / \mathrm{Al}$-tartrate, $\mathrm{Mg}_{3} / \mathrm{Al}$-laurate and $\mathrm{Mg}_{3} / \mathrm{Al}$-oxalate (see Figure 1)) are shifted to smaller $2 \theta$ angle values. The similar shift was observed and for the LDHs modified with benzoic carboxylates (Figure 2). The determined values of the lattice parameters $c$ (see Table 1) were monotonically increased from

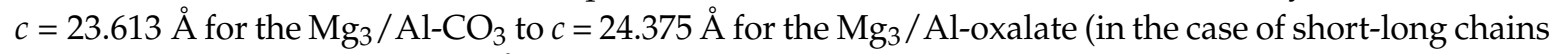
intercalation) and to $c=24.492 \AA$ for the $\mathrm{Mg}_{3} / \mathrm{Al}_{1}$-4-biphenylacetonate (in the case of derivatives of aromatic hydrocarbons). These results led us to conclude that all anions studied have been successfully intercalated to the $\mathrm{Mg}_{3} / \mathrm{Al} \mathrm{LDH}$ structure. 
Table 1. The determined values of $d$ spacing and lattice parameters of anion-intercalated $\mathrm{Mg}_{3} / \mathrm{Al}$ LDHs. The standard deviations for all measurements do not exceed \pm 0.0005 .

\begin{tabular}{|c|c|c|c|c|}
\hline \multirow{2}{*}{ Sample } & \multicolumn{2}{|c|}{ Basal Spacing/Å } & \multicolumn{2}{|c|}{ Cell Parameter/Å } \\
\hline & $d(003)$ & $\mathrm{d}(\mathbf{1 1 0})$ & a & c \\
\hline $\mathrm{Mg}_{3} / \mathrm{Al}-\mathrm{CO}_{3}$ & 7.8744 & 1.5350 & 3.068 & 23.613 \\
\hline $\mathrm{Mg}_{3} / \mathrm{Al}$-oxalate & 8.1286 & 1.5385 & 3.076 & 24.375 \\
\hline $\mathrm{Mg}_{3} / \mathrm{Al}$-laurate & 8.0905 & 1.5380 & 3.075 & 24.261 \\
\hline $\mathrm{Mg}_{3} / \mathrm{Al}$-tartarate & 7.9970 & 1.5359 & 3.070 & 23.981 \\
\hline $\mathrm{Mg}_{3} / \mathrm{Al}$-malonate & 7.9568 & 1.5343 & 3.067 & 23.860 \\
\hline $\mathrm{Mg}_{3} / \mathrm{Al}$-succinate & 7.9454 & 1.5333 & 3.065 & 23.826 \\
\hline $\mathrm{Mg}_{3} / \mathrm{Al}-4$-biphenylacetonate & 8.1675 & 1.5396 & 3.078 & 24.492 \\
\hline $\mathrm{Mg}_{3} /$ Al-benzoate & 8.0875 & 1.5384 & 3.075 & 24.252 \\
\hline $\mathrm{Mg}_{3} / \mathrm{Al}-4$-methylbenzoate & 8.0564 & 1.5383 & 3.075 & 24.159 \\
\hline $\mathrm{Mg}_{3} / \mathrm{Al}-1,3,5$-benzentricarboxylate & 8.0328 & 1.5373 & 3.073 & 24.088 \\
\hline $\mathrm{Mg}_{3} / \mathrm{Al}-4$-dimethylaminobenzoate & 7.8907 & 1.5324 & 3.063 & 23.662 \\
\hline
\end{tabular}

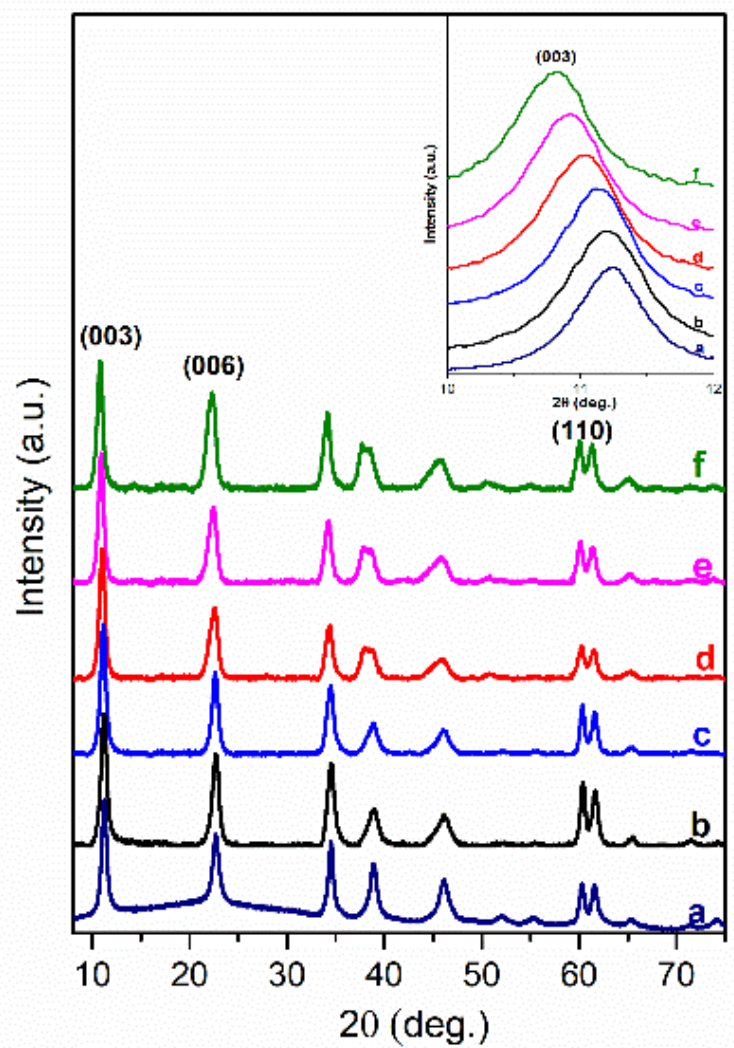

Figure 1. XRD patterns of $\mathrm{Mg}_{3} / \mathrm{Al}-\mathrm{CO}_{3}$ layered double hydroxides (LDH) (a) and $\mathrm{Mg}_{3} / \mathrm{Al}-\mathrm{CO}_{3}$ intercalated with organic anions: $\mathrm{Mg}_{3} / \mathrm{Al}$-succinate (b), $\mathrm{Mg}_{3} / \mathrm{Al}$-malonate (c), $\mathrm{Mg}_{3} / \mathrm{Al}$-tartrate (d), $\mathrm{Mg}_{3} / \mathrm{Al}$-laurate (e), and $\mathrm{Mg}_{3} / \mathrm{Al}$-oxalate (f). 


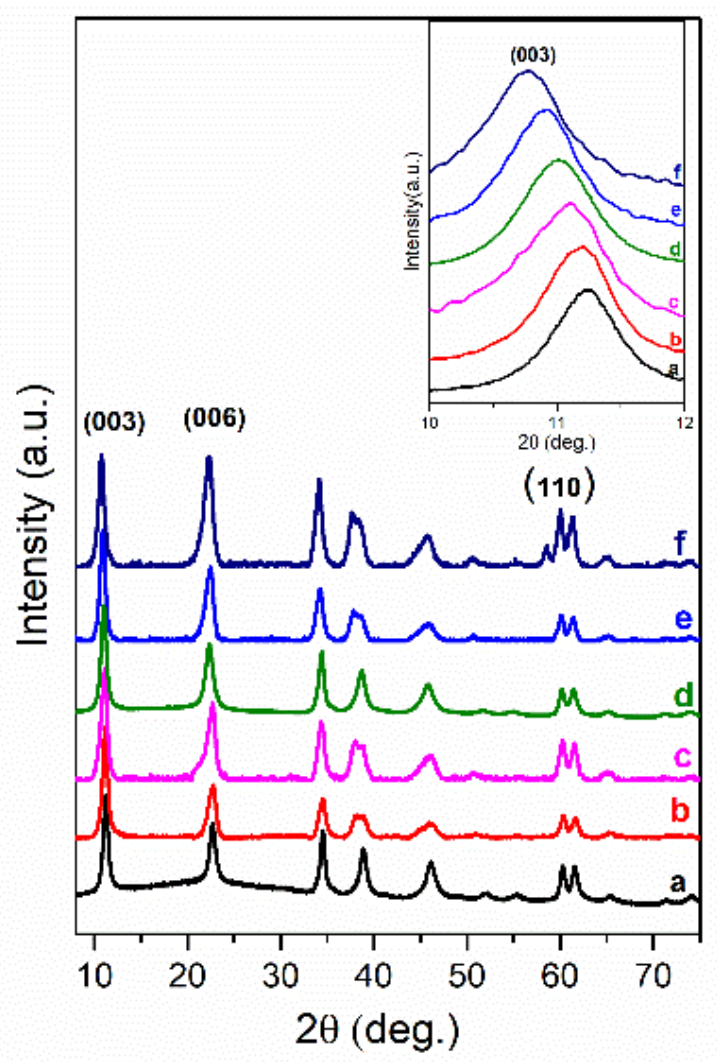

Figure 2. $\mathrm{XRD}$ patterns of $\mathrm{Mg}_{3} / \mathrm{Al}-\mathrm{CO}_{3} \mathrm{LDH}$ (a) and $\mathrm{Mg}_{3} / \mathrm{Al}-\mathrm{CO}_{3}$ intercalated with organic anions $\mathrm{Mg}_{3}$ / $\mathrm{Al}$-4-dimethylaminobenzoate (b), $\mathrm{Mg}_{3} / \mathrm{Al}-4$-methylbenzoate (c), $\mathrm{Mg}_{3} / \mathrm{Al}-1,3,5-$ benzentricarboxylate (d), $\mathrm{Mg}_{3} / \mathrm{Al}$-benzoate (e) and $\mathrm{Mg}_{3} / \mathrm{Al}$-4-biphenylacetonate (f).

The dimensions of anions (Table 2) show that the oxalate anion of intercalated LDH was the smallest by length $(1.94 \AA)$ and having the highest height $(5.01 \AA)$. Since the determined $c$ parameter for the $\mathrm{Mg}_{3} / \mathrm{Al}$-oxalate modified LDH is the largest between short-long chains intercalation, it can be deduced that the oxalate anion has specific vertical orientation in the LDHs (see Figure 3). In the case of aromatic hydrocarbons, the height of all anions is very similar. Therefore, the 4-biphenylacetonate which has a largest length (10.06 $⿱$ ) has horizontal orientation in the LDH structure (Figure 3). The $\mathrm{Mg}_{3} / \mathrm{Al}$-oxalate and the $\mathrm{Mg}_{3} / \mathrm{Al}$-4-biphenylacetonate $\mathrm{LDH}$ having similar basal spacings correspond to the intercalated LDHs with vertical and horizontal anion orientations in which they are grafting into the hydroxide layers. There are spherical energetic interferences between $-\mathrm{CH}_{3}$ groups of anions and $\mathrm{M}-\mathrm{OH}$ hydroxide layers what cause difficult intercalation in the LDH structure. The formation of hydrogen bonds between water molecules in the layers, the hydroxide layers, the interlayer anions, and among the $\mathrm{H}_{2} \mathrm{O}$ molecules themselves is possible. The orientation of oxalate anion possibly is related to the formation of $\mathrm{H}_{2} \mathrm{O}$ molecules more compact structures with the two $-\mathrm{COO}^{-}$groups than with the hydrophobic ends of the monocarboxylate. Four oxalate -COO- groups are distributed perpendicular to the layers, with two O-atoms coordinated to different hydroxide layers. In the case of 4-biphenylacetonate, the -COO-groups are orientated differently, and the O-atoms of its $-\mathrm{COO}^{-}$groups that situated parallel to the layers can occupy $\mathrm{M}-\mathrm{OH}$ sites along the $\mathrm{H}-\mathrm{H}$ vectors, whereas those -COO- tend to occupy the centers of the $\mathrm{M}-\mathrm{OH}$ triangles. 
Table 2. Formula and dimensions of anions.

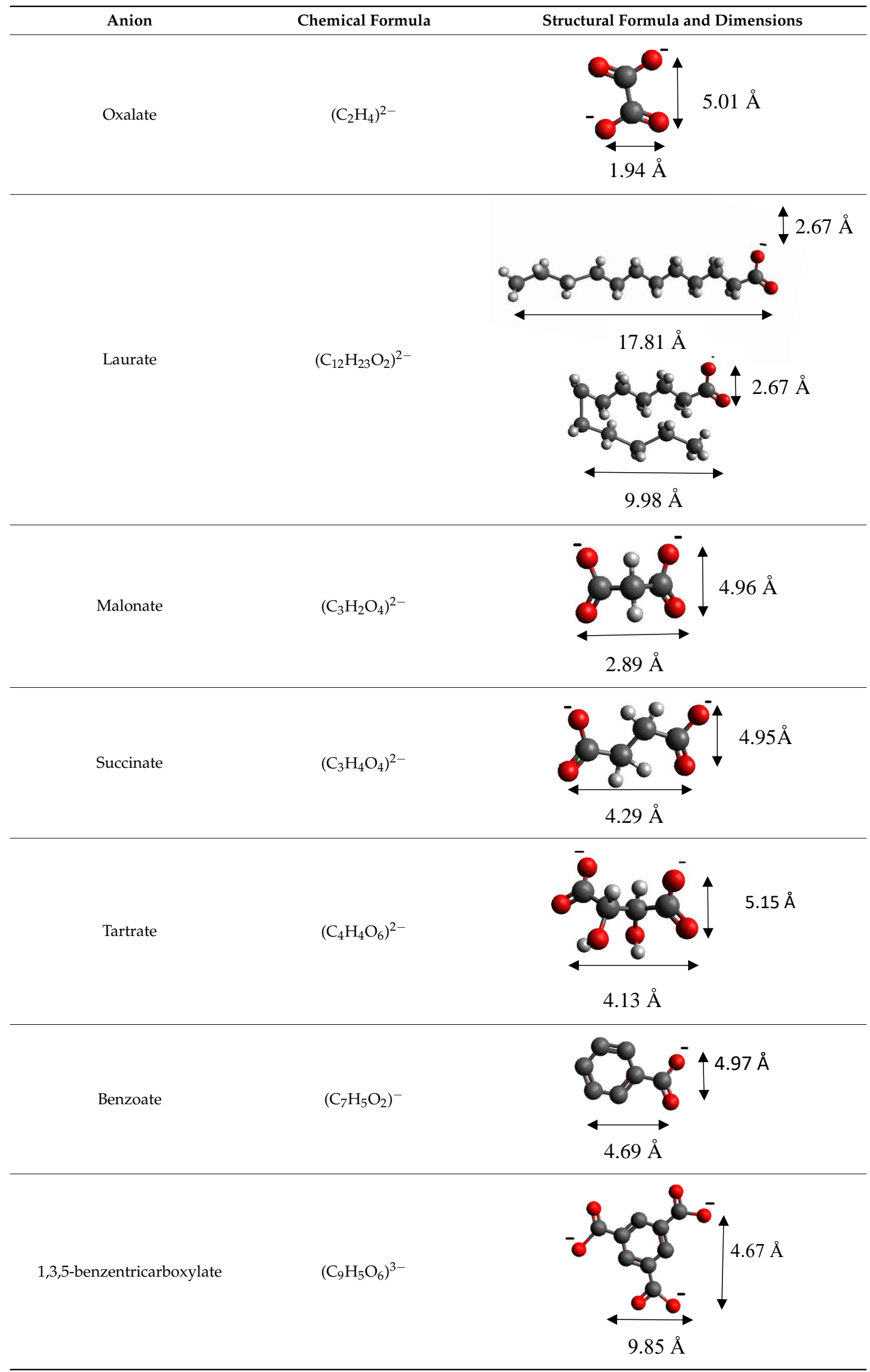


Table 2. Cont.

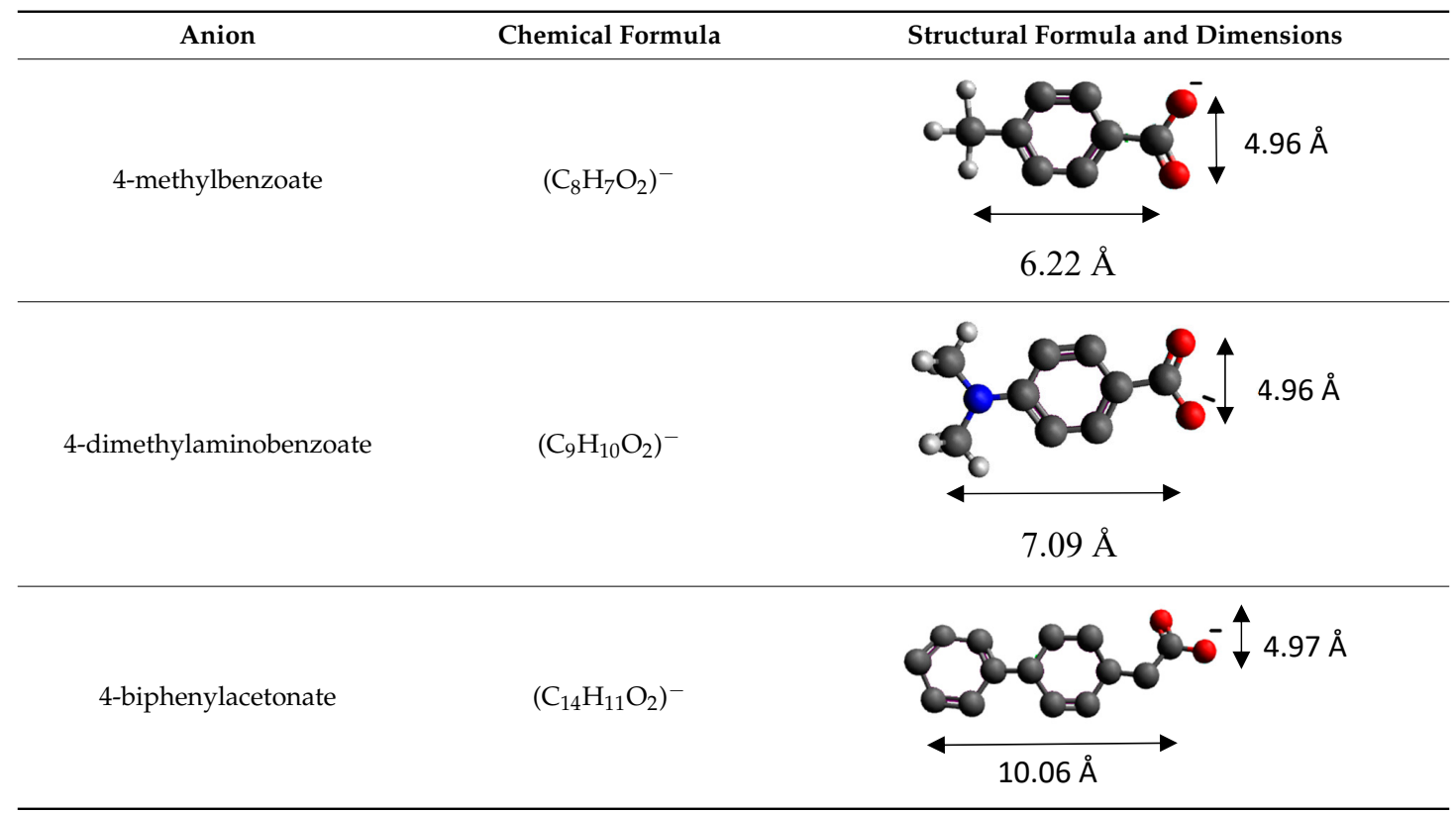

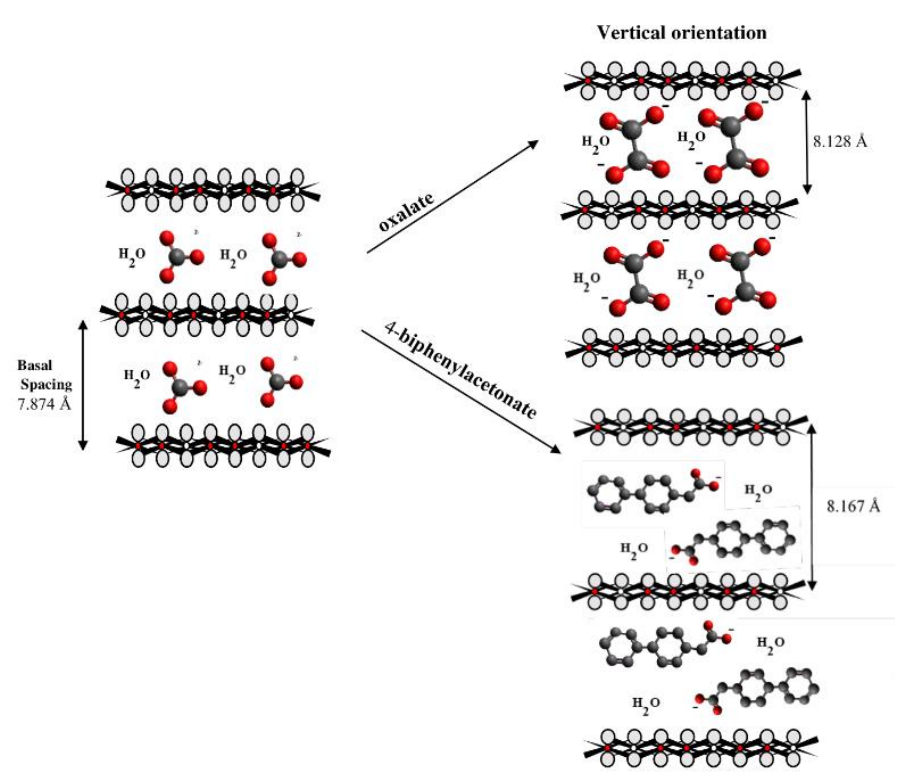

Figure 3. A schematic structure of LDHs with interlayer carbonate anion and the specific orientation of oxalate and 4-biphenylacetonate anions between the layers.

Europium substitution effects incorporating $\mathrm{Eu}^{3+}$ at the $\mathrm{Al}^{3+}$ positions in $\mathrm{Mg}_{3} \mathrm{Al}$-organic anion LDHs have been investigated. According to [27], the $\mathrm{Mg}_{3} / \mathrm{Al}_{0.99} \mathrm{Eu}_{0.01}$ (with $1 \mathrm{~mol} \%$ of Eu) have been prepared and intercalated with different organic anions. The XRD patterns (Figures 4 and 5) for the hybrid inorganic-organic $\mathrm{Mg}_{3} / \mathrm{Al}_{0.99} \mathrm{Eu}_{0.01} \mathrm{LDHs}$ showed, that the position of the (003) diffraction line is relevant to the interlayer distance and depends on the size of the intercalated organic anion. Surprisingly, the shift of the diffraction lines in the XRD patterns of intercalated with different organic anions of $\mathrm{Eu}^{3+}$-substituted LDHs is less pronounced in comparison with the samples without europium. This might be due to the reason, that the electrostatic attraction between mixed-metal cations and anions is weaker influencing on the distance of interlayer. 


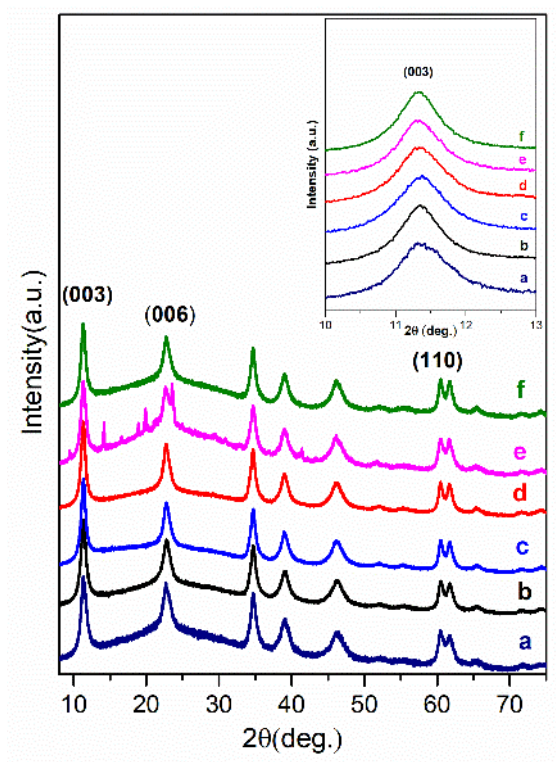

Figure 4. $\mathrm{XRD}$ patterns of $\mathrm{Mg}_{3} / \mathrm{Al}_{0.99} \mathrm{Eu}_{0.01}-\mathrm{CO}_{3}$ (a) and hybrid inorganic-organic LDHs: $\mathrm{Mg}_{3} / \mathrm{Al}_{0.99} \mathrm{Eu}_{0.01}$-succinate (b), $\mathrm{Mg}_{3} / \mathrm{Al}_{0.99} \mathrm{Eu}_{0.01}$-malonate (c), $\mathrm{Mg}_{3} / \mathrm{Al}_{0.99} \mathrm{Eu}_{0.01}$-tartrate (d), $\mathrm{Mg}_{3} / \mathrm{Al}_{0.99} \mathrm{Eu}_{0.01}$-laurate (e) and $\mathrm{Mg}_{3} / \mathrm{Al}_{0.99} \mathrm{Eu}_{0.01}$-oxalate (f).

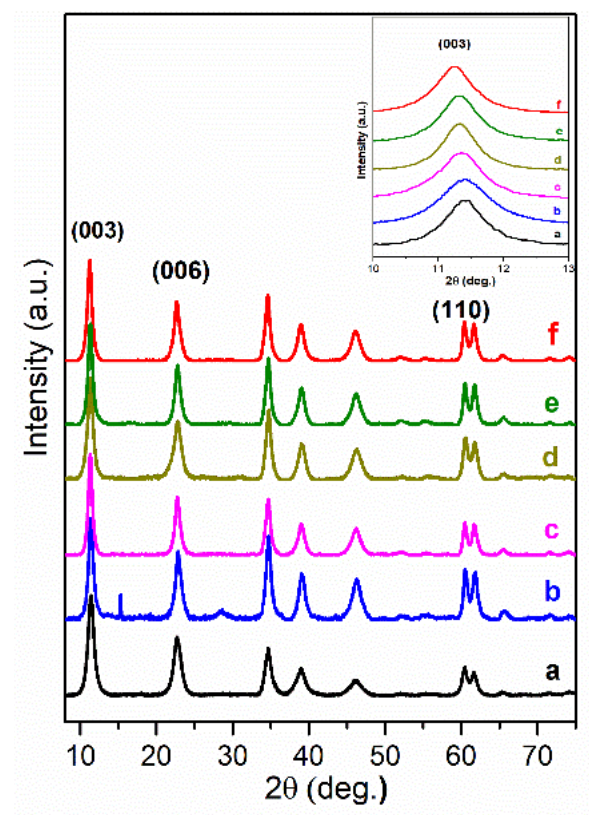

Figure 5. $\mathrm{XRD}$ patterns of $\mathrm{Mg}_{3} / \mathrm{Al}_{0.99} \mathrm{Eu}_{0.01}-\mathrm{CO}_{3}$ (a) and hybrid inorganic-organic LDHs: $\quad \mathrm{Mg}_{3} / \mathrm{Al}_{0.99} \mathrm{Eu}_{0.01}$-4-dimethylaminobenzoate (b), $\mathrm{Mg}_{3} / \mathrm{Al}_{0.99} \mathrm{Eu}_{0.01}$-4-methylbenzoate (c), $\quad \mathrm{Mg}_{3} / \mathrm{Al}_{0.99} \mathrm{Eu}_{0.01}$-1,3,5-benzentricarboxylate (d), $\mathrm{Mg}_{3} / \mathrm{Al}_{0.99} \mathrm{Eu}_{0.01}$-benzoate (e) and $\mathrm{Mg}_{3} / \mathrm{Al}_{0.99} \mathrm{Eu}_{0.01}$-4-biphenylacetonate (f).

FT-IR spectra of $\mathrm{Mg}_{3} / \mathrm{Al}, \mathrm{Mg}_{3} / \mathrm{Al}_{0.99} \mathrm{Eu}_{0.01}$ and hybrid inorganic-organic LDHs are shown in Figures 6 and 7. The spectra of all samples are almost identical with very little differences. The broad absorptions visible at $3500-3000 \mathrm{~cm}^{-1}$ are characteristic vibrations of (-OH) groups [11]. The most intensive absorption bands detectible at $1360 \mathrm{~cm}^{-1}$ could be assigned to the asymmetric vibrations of $\mathrm{CO}_{3}{ }^{2-}$, which still exists in the interlayer of intercalated LDHs along with intercalated organic anions. The absorption bands in the range of $1570-1627 \mathrm{~cm}^{-1}$ are assigned to the of carbon-oxygen bonds of $\left(-\mathrm{COO}^{-}\right)$group. The first absorption band is related to the asymmetric vibration of the carboxylate group $\left(v_{\mathrm{as}}, \mathrm{COO}^{-}\right)$and the second is attributable to the symmetric 
vibration of the carboxylate group $\left(v_{\mathrm{s}}, \mathrm{COO}^{-}\right)$, demonstrating the coordination of carboxylates to $\mathrm{Mg}_{3}$ / Al-benzoate (h), $\mathrm{Mg}_{3} / \mathrm{Al}-1,3,5$-benzentricarboxylate (i), $\mathrm{Mg}_{3} / \mathrm{Al}$-4-methylbenzoate (Figure 6) and $\mathrm{Mg}_{3} / \mathrm{Al}_{0.99} \mathrm{Eu}_{0.01}$-benzoate $(\mathrm{g}), \mathrm{Mg}_{3} / \mathrm{Al}_{0.99} \mathrm{Eu}_{0.01}-1,3,5$-benzentricarboxylate (h) (Figure 7). The absorption bands visible at $2850-2937 \mathrm{~cm}^{-1}$ are due to the $\mathrm{C}-\mathrm{H}$ stretching vibrations of methylene $\left(-\mathrm{CH}_{2}-\right)$ of the organic compounds. Thus, the FT-IR results prove the formation of the inorganic-organic hybrids and interactions of the introduced organic species with the LDH layers.
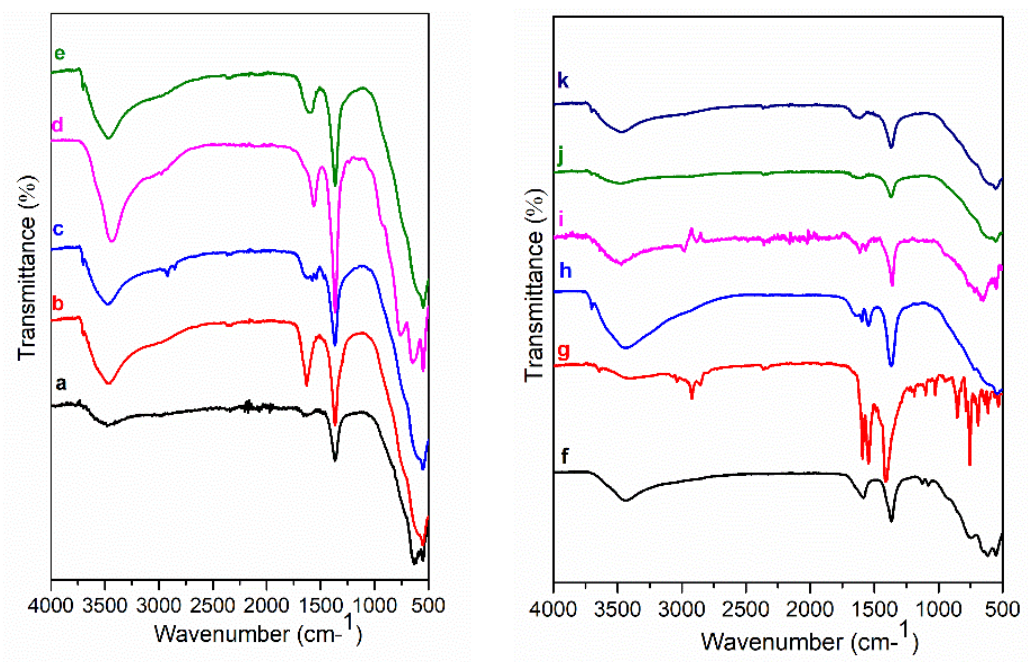

Figure 6. FT-IR spectra of $\mathrm{Mg}_{3} / \mathrm{Al}-\mathrm{CO}_{3}$ (a) and hybrid inorganic-organic $\mathrm{LDHs}: \mathrm{Mg}_{3} / \mathrm{Al}$-oxalate (b), $\mathrm{Mg}_{3} / \mathrm{Al}$-laurate (c), $\mathrm{Mg}_{3} / \mathrm{Al}$-succinate (d), $\mathrm{Mg}_{3} / \mathrm{Al}$-malonate (e). FT-IR spectra of $\mathrm{Mg}_{3} / \mathrm{Al}$-tartrate (f), $\mathrm{Mg}_{3} / \mathrm{Al}$-4-biphenylacetonate (g), $\mathrm{Mg}_{3} /$ Al-benzoate (h), $\mathrm{Mg}_{3} / \mathrm{Al}$-1,3,5-benzentricarboxylate (i), $\mathrm{Mg}_{3} / \mathrm{Al}-4$-methylbenzoate (j) and $\mathrm{Mg}_{3} / \mathrm{Al}-4$-dimethylaminobenzoate (k).
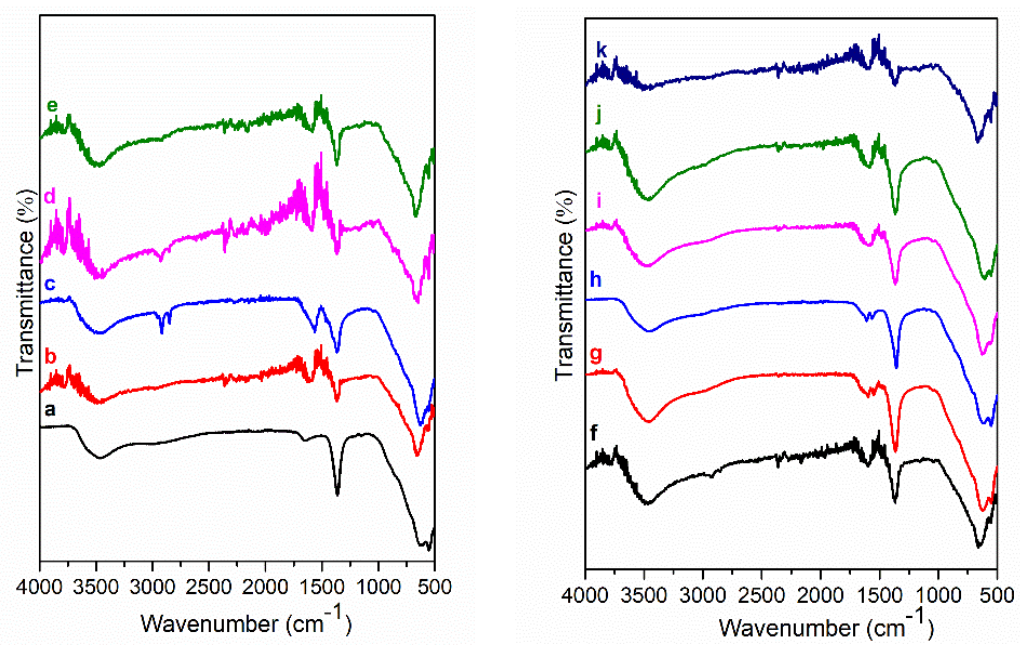

Figure 7. FT-IR spectra of $\mathrm{Mg}_{3} / \mathrm{Al}_{0.99} \mathrm{Eu}_{0.01}-\mathrm{CO}_{3}$ (a) and hybrid inorganic-organic LDHs: $\quad \mathrm{Mg}_{3} / \mathrm{Al}_{0.99} \mathrm{Eu}_{0.01}$-oxalate (b), $\quad \mathrm{Mg}_{3} / \mathrm{Al}_{0.99} \mathrm{Eu}_{0.01}$-laurate (c), $\mathrm{Mg}_{3} / \mathrm{Al}_{0.99} \mathrm{Eu}_{0.01}$ succinate (d), $\mathrm{Mg}_{3} / \mathrm{Al}_{0.99} \mathrm{Eu}_{0.01}$-malonate (e). FT-IR spectra of $\mathrm{Mg}_{3} / \mathrm{Al}_{0.99} \mathrm{Eu}_{0.01}$-tartrate (f), $\mathrm{Mg}_{3} / \mathrm{Al}_{0.99} \mathrm{Eu}_{0.01}$-benzoate (g), $\quad \mathrm{Mg}_{3} / \mathrm{Al}_{0.99} \mathrm{Eu}_{0.01}$-1,3,5-benzentricarboxylate (h), $\mathrm{Mg}_{3} / \mathrm{Al}_{0.99}$ $\mathrm{Eu}_{0.01}$-1-4-biphenylacetonate (i), $\mathrm{Mg}_{3} / \mathrm{Al}_{0.99} \mathrm{Eu}_{0.01}$-4-methylbenzoate (j) and $\mathrm{Mg}_{3} / \mathrm{Al}_{0.99} \mathrm{Eu}_{0.01^{-}}$ 4-dimethylaminobenzoate (k).

The emission spectra obtained at room temperature of $\mathrm{Mg}_{3} / \mathrm{Al}_{0.99} \mathrm{Eu}_{0.01}$ and $\mathrm{Mg}_{3} / \mathrm{Al}_{0.99} \mathrm{Eu}_{0.01}$ samples intercalated with benzoate, oxalate, laurate, malonate, succinate, tartrate, 1,3,5-benzentricarboxylate (BTC), 4-methylbenzoate (MB), 4-dimethylaminobenzoate (DMB) and 4-biphenylacetonate $(\mathrm{BPhAc})$ anions $\left(\lambda_{\mathrm{ex}}=394 \mathrm{~nm}\right)$ are presented in Figure 8. The emission spectra 
of $\mathrm{Mg}_{3} / \mathrm{Al}_{0.99} \mathrm{Eu}_{0.01}$ - organic anion LDHs show four main emission lines between $550 \mathrm{~nm}$ and $740 \mathrm{~nm}$. All observed emission bands are due to ${ }^{5} \mathrm{D}_{0}-{ }^{7} \mathrm{~F}_{\mathrm{J}}(\mathrm{J}=1,2,3,4)$ transitions of $\mathrm{Eu}^{3+}$ ions. According to the literature, the emissions are ${ }^{5} \mathrm{D}_{0} \rightarrow{ }^{7} \mathrm{~F}_{1}(590 \mathrm{~nm}),{ }^{5} \mathrm{D}_{0} \rightarrow{ }^{7} \mathrm{~F}_{2}(613 \mathrm{~nm}),{ }^{5} \mathrm{D}_{0} \rightarrow{ }^{7} \mathrm{~F}_{3}(650 \mathrm{~nm})$ and ${ }^{5} \mathrm{D}_{0} \rightarrow{ }^{7} \mathrm{~F}_{4}(697 \mathrm{~nm})$ transitions typical of $\mathrm{Eu}^{3+}$ ion [28]. The $\mathrm{Eu}^{3+}$ ions occupy a low-symmetry site, since the emission due to ${ }^{5} \mathrm{D}_{0} \rightarrow{ }^{7} \mathrm{~F}_{2}$ transition is the strongest. Moreover, the results obtained indicate that the excitation energy to the $\mathrm{Eu}^{3+}$ ion in most of the cases is transferring from the organic anion ligands increasing the intensity of emission of the LDHs. Two mechanisms of intramolecular and intermolecular energy transfer between lanthanide ions and organic molecules have been suggested [29]. As was stated in [29], the intensity of emission of lanthanide distributed in host matrixes is affected by the energy matching degree between organic ligands and lanthanide ions. Evidently, when the energy matching degree is better, the energy transfer efficiency is higher and, consequently, the emission intensity of the compound is higher. The potency to absorb the UV radiation by interlayer organic anions and possible transfer this energy to the $\mathrm{Eu}^{3+}$ center by the interaction between the carboxyl oxygen of the intercalated anions with the hydrogen of the $\mathrm{M}(\mathrm{OH})_{6}$ octahedra via a hydrogen bond was suggested. The tartrate and benzoate having the strong basicity, showed higher ability to absorb the light [30]. Carbonate is a weaker base, thus transferring less energy to $\mathrm{Eu}^{3+}$ ions. The aromatic ring in the benzene can also influence the levels of resonant energy of lanthanide ions. As we can see from emission spectra the $\mathrm{Mg}_{3} / \mathrm{Al}_{0.99} \mathrm{Eu}_{0.01}$-tartrate and $\mathrm{Mg}_{3} / \mathrm{Al}_{0.99} \mathrm{Eu}_{0.01}$-benzoate LDHs show the highest emission intensity to compare with LDHs containing other organic ligands. Carboxylate and carbonyl groups connected with aromatic ring usually decrease the intensity of emission. The energy matching degree in the benzoate and $\mathrm{Eu}$ (III) complex obviously should be enhanced influencing the intensity of emission [31]. Moreover, the bridge of methylene groups $-\mathrm{CH}_{2}$ - can break up the conjugated $\pi$-electron system [18].

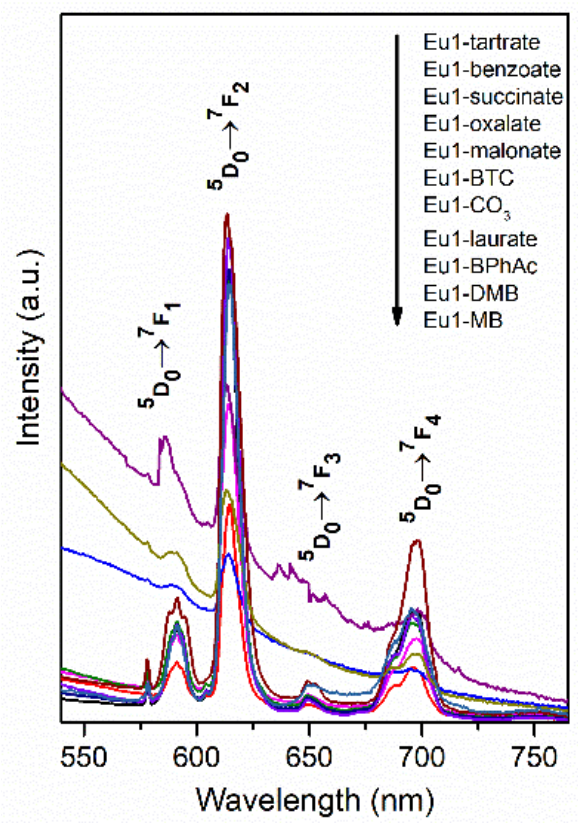

Figure 8. Emission spectra of $\mathrm{Mg}_{3} / \mathrm{Al}_{0.99} \mathrm{Eu}_{0.01}$ and $\mathrm{LDHs}$ intercalated with tartrate, benzoate, succinate, oxalate, malonate, 1,3,5-benzentricarboxylate, laurate, 4-biphenylacetonate, 4-dimethylaminobenzoate and 4-methylbenzoate. $(\mathrm{Ex}=394 \mathrm{~nm})$.

The SEM micrographs depicted in Figure 9 represent the microstructure of $\mathrm{Mg}_{3} / \mathrm{Al}-\mathrm{CO}_{3}$ and $\mathrm{Mg}_{3} / \mathrm{Al}_{0.99} \mathrm{Eu}_{0.01}-\mathrm{CO}_{3}$ layered double hydroxides. As seen, the solids are composed of particles having plate form and size about of 200-400 nm. The representative SEM micrographs of LDHs intercalated with different organic anions are shown in Figure 10. The surface microstructure still represents the characteristic features of LDHs [32], however, the particle sizes increased considerably 
(500-600 nm). Finally, the SEM micrographs of the samples which showed the most intensive emission $\mathrm{Mg}_{3} / \mathrm{Al}_{0.99} \mathrm{Eu}_{0.01}$-tartrate and $\mathrm{Mg}_{3} / \mathrm{Al}_{0.99} \mathrm{Eu}_{0.01}$-benzoate are presented in Figure 11. Evidently, the surface microstructure of these two samples is almost identical. The hexagonally shaped particles with the size of $\sim 450-500 \mathrm{~nm}$ have formed.
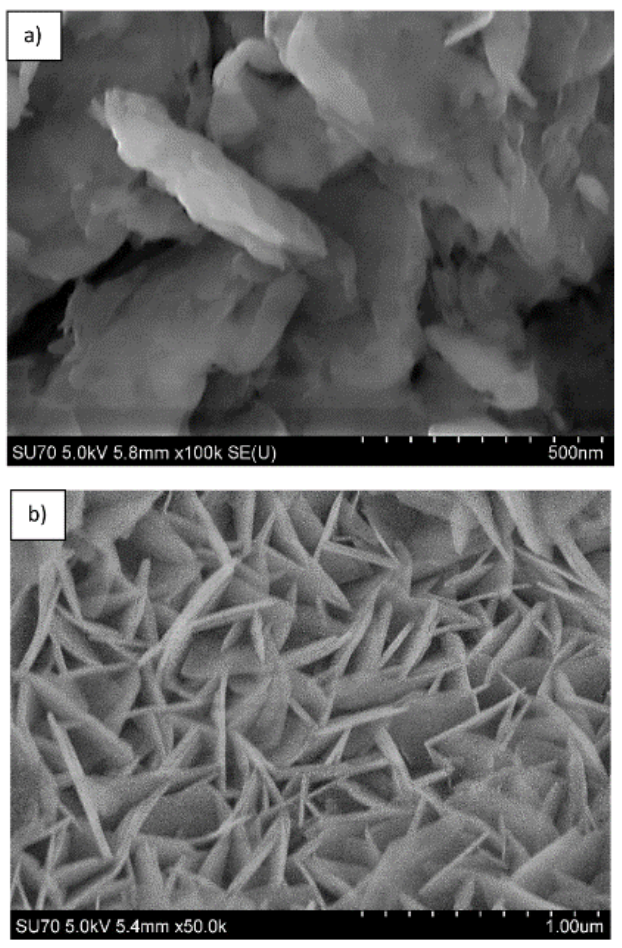

Figure 9. $\mathrm{SEM}$ micrographs of $\mathrm{Mg}_{3} / \mathrm{Al}-\mathrm{CO}_{3}(\mathbf{a})$ and $\mathrm{Mg}_{3} / \mathrm{Al}_{0.99} \mathrm{Eu}_{0.01}-\mathrm{CO}_{3}$ (b) $\mathrm{LDHs}$.
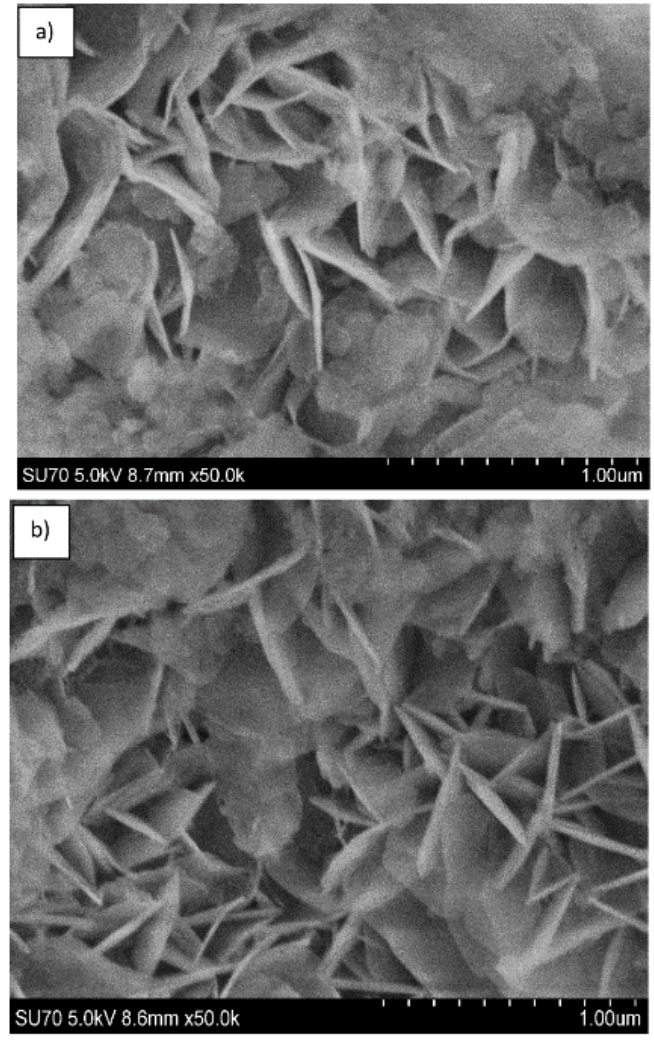

Figure 10. SEM micrographs of $\mathrm{Mg}_{3} / \mathrm{Al}$-oxalate (a) and $\mathrm{Mg}_{3} / \mathrm{Al}-4$-biphenylacetonate (b) LDHs. 

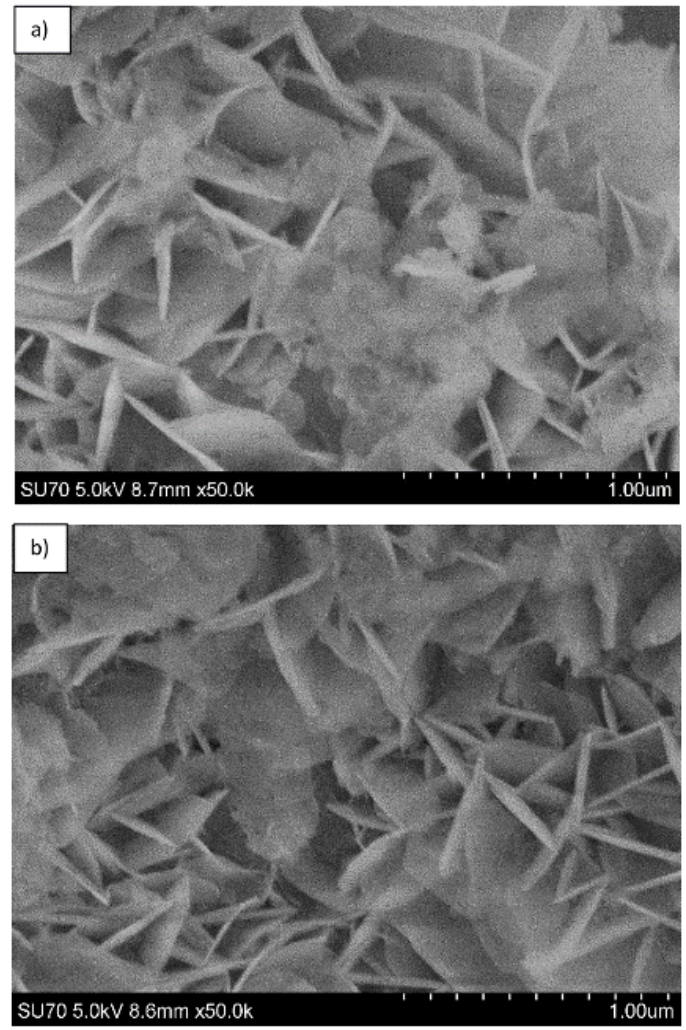

Figure 11. SEM micrographs of $\mathrm{Mg}_{3} / \mathrm{Al}_{0.99} \mathrm{Eu}_{0.01}$-tartrate (a) and $\mathrm{Mg}_{3} / \mathrm{Al}_{0.99} \mathrm{Eu}_{0.01}$-benzoate (b) LDHs.

\section{Conclusions}

$\mathrm{Mg}_{3} / \mathrm{Al}-\mathrm{CO}_{3}$ and $\mathrm{Mg}_{3} / \mathrm{Al}_{0.99} \mathrm{Eu}_{0.01} \mathrm{LDHs}$ intercalated with benzoate, oxalate, laurate, malonate, succinate, tartrate, 1,3,5-benzentricarboxylate (BTC), 4-methylbenzoate (MB), 4-dimethylaminobenzoate (DMB) and 4-biphenylacetonate (BPhAc) were prepared by sol-gel processing. The XRD analysis results clearly showed that the positions of diffraction peaks (003) of LDHs intercalated with anions were shifted to smaller $2 \theta$ angle values. However, the shift of the diffraction lines in the XRD patterns of intercalated with different organic anions of $\mathrm{Eu}^{3+}$-substituted LDHs was less pronounced in comparison with the samples without europium. The FT-IR results demonstrated once again the formation of the inorganic-organic hybrids and interaction of the organic ions with the LDH layers. The obtained results let us to conclude that depending on the size of anions these species could have specific vertical or horizontal orientations in the LDH structure. The microstructure of $\mathrm{Mg}_{3} / \mathrm{Al}-\mathrm{CO}_{3}, \mathrm{Mg}_{3} / \mathrm{Al}_{0.99} \mathrm{Eu}_{0.01}-\mathrm{CO}_{3}$ and $\mathrm{Mg}_{3} / \mathrm{Al}_{0.99} \mathrm{Eu}_{0.01}$-organic anion was typical for LDH samples. The SEM images showed the formation of hexagonally shaped plate-like particles of LDHs of 200-600 $\mathrm{nm}$ in size with high degree of agglomeration. The room temperature luminescence of $\mathrm{Mg}_{3} / \mathrm{Al}_{0.99} \mathrm{Eu}_{0.01}$ and $\mathrm{Mg}_{3} / \mathrm{Al}_{0.99} \mathrm{Eu}_{0.01}$ samples intercalated with benzoate, oxalate, laurate, malonate, succinate, tartrate, 1,3,5-benzentricarboxylate (BTC), 4-methylbenzoate (MB), 4-dimethylaminobenzoate (DMB) and 4-biphenylacetonate (BPhAc) anions under excitation at $394 \mathrm{~nm}$ was investigated. In all spectra, the typical four emission bands due to transitions of ${ }^{5} \mathrm{D}_{0} \rightarrow{ }^{7} \mathrm{~F}_{1}$ $(590 \mathrm{~nm}),{ }^{5} \mathrm{D}_{0} \rightarrow{ }^{7} \mathrm{~F}_{2}(613 \mathrm{~nm}),{ }^{5} \mathrm{D}_{0} \rightarrow{ }^{7} \mathrm{~F}_{3}(650 \mathrm{~nm})$ and ${ }^{5} \mathrm{D}_{0} \rightarrow{ }^{7} \mathrm{~F}_{4}(697 \mathrm{~nm})$ of Eu $\mathrm{uu}^{3+}$ ion were determined. The $\mathrm{Mg}_{3} / \mathrm{Al}_{0.99} \mathrm{Eu}_{0.01}$-tartrate and $\mathrm{Mg}_{3} / \mathrm{Al}_{0.99} \mathrm{Eu}_{0.01}$-benzoate LDHs showed the highest emission intensity to compare with LDHs containing other organic ligands.

Author Contributions: Conceptualization, A.S. and A.K.; methodology, A.S.; software, A.S.; validation, T.C.K.Y., L.P. and A.K.; formal analysis, A.K.; investigation, A.S.; resources, L.P.; data curation, T.C.K.Y.; writing-original draft preparation, A.S.; writing-review and editing, A.K.; visualization, T.C.K.Y.; supervision, A.K.; project administration, A.K.; funding acquisition, A.K.

Funding: This research received no external funding. 
Acknowledgments: L. Pavasaryte is thankful for the Post-Doctoral Fellowship administrated through the National Taipei University of Technology.

Conflicts of Interest: The authors declare no conflict of interest.

\section{References}

1. Evans, D.E.; Slade, R.C.T. Layered Double Hydroxides; Springer-Verlag: Berlin, Germany, 2005; Volume 119, pp. $1-87$.

2. Khan, A.I.; O'Hare, D. Intercalation chemistry of layered double hydroxides: recent developments and applications. J. Mater. Chem. 2002, 12,3191-3198. [CrossRef]

3. Miyata, S. Anion-exchange properties of hydrotalcite-like compounds. Clays Clay Miner. 1983, 31, $305-311$. [CrossRef]

4. Costa, D.G.; Rocha, A.B.; Souza, W.F.; Chiaro, S.S.X.; Leitao, A.A. Structural model proposition and thermodynamic and vibrational analysis of hydrotalcite-like compounds by DFT calculations. J. Phys. Chem. 2010, 114, 14133-14140. [CrossRef]

5. Kim, N.; Harale, A.; Tsotsis, T.T.; Sahimi, M. Atomistic simulation of nanoporous layered double hydroxide materials and their properties. II. Adsorption and diffusion. J. Chem. Phys. 2007, 127, 224701. [CrossRef] [PubMed]

6. Wang, J.; Kirkpatrick, G.K.R.J.; Hou, X. Interlayer Structure and Dynamics of $\mathrm{Cl}^{-}-\mathrm{LiAl}_{2}$-Layered Double Hydroxide: ${ }^{35} \mathrm{Cl}$ NMR Observations and Molecular Dynamics Modeling. Chem. Mater. 2002, 14, $2078-2085$.

7. Pavlovic, M.; Adok-Sipiczki, M.; Nardin, C.; Pearson, S.; Bourgeat-Lami, E.; Prevot, V.; Szilagyi, I. Effect of MacroRAFT Copolymer Adsorption on the Colloidal Stability of Layered Double Hydroxide Nanoparticles. Langmuir 2015, 31, 12609-12617. [CrossRef] [PubMed]

8. Xu, Z.P.; Jin, Y.; Li, S.; Hao, Z.; Lu, G.Q. Surface charging of layered double hydroxides during dynamic interactions of anions at the interfaces. J. Colloid Interface Sci. 2008, 326, 522-529. [CrossRef] [PubMed]

9. Pavlovic, M.; Huber, R.; Adok-Sipiczki, M.; Nardina, C.; Szilagyi, I. Ion specific effects on the stability of layered double hydroxide colloids. Soft Matter 2016, 12, 4024-4033. [CrossRef] [PubMed]

10. Pavlovic, M.; Rouster, P.; Oncsik, T.; Szilagyi, I. Tuning Colloidal Stability of Layered Doubl Hydroxides: from Monovalent Ions to Polyelectrolytes. ChemPlusChem 2017, 82, 121-131. [CrossRef]

11. Liu, L.; Wang, Q.; Gao, C.; Chen, H.; Liu, W.; Tang, Y. Dramatically Enhanced Luminescence of Layered Terbium Hydroxides as Induced by the Synergistic Effect of $\mathrm{Gd}^{3+}$ and Organic Sensitizers. J. Phys. Chem. C 2014, 118, 14511-14520. [CrossRef]

12. Kovar, P.; Pospisil, M.; Nocchetti, M.; Capkova, P.; Melanova, K. Molecular modeling of layered double hydroxide intercalated with benzoate, modeling and experiment. J. Mol. Model. 2007, 13, 937-942. [CrossRef] [PubMed]

13. Posati, T.; Costantino, F.; Latterini, L.; Nocchetti, M.; Paolantoni, M.; Tarpani, L. New insights on the incorporation of lanthanide ions into nanosized layered double hydroxides. Inorg. Chem. 2012, 51, 13229. [CrossRef] [PubMed]

14. Zhao, Y.; Li, J.G.; Fang, F.; Chu, N.; Ma, H.; Yang, X. Structure and luminescence behaviour of as-synthesized, calcined, and restored MgAlEu-LDH with high crystallinity. Dalton Trans. 2012, 41, 12175-12184. [CrossRef] [PubMed]

15. Salak, A.N.; Tedim, J.; Kuznetsova, A.I.; Ribeiro, J.L.; Vieira, L.G.; Zheludkevich, M.L.; Ferreira, M.G.S. Comparative $\mathrm{X}$-ray diffraction and infrared spectroscopy study of $\mathrm{Zn}$-Al layered double hydroxides: Vanadate vs nitrate. Chem. Phys. 2012, 397, 102-108. [CrossRef]

16. Constantino, U.; Constantino, F.; Elisei, F.; Latterini, I.; Nocchetti, M. Coupling physical chemical techniques with hydrotalcite-like compounds to exploit their structural features and new multifunctional hybrids with luminescent properties. Phys. Chem. Chem. Phys. 2013, 32, 13254-13269. [CrossRef] [PubMed]

17. Smalenskaite, A.; Salak, A.N.; Ferreira, M.G.S.; Skaudzius, R.; Kareiva, A. Sol-gel synthesis and characterization of hybrid inorganic-organic $\mathrm{Tb}(\mathrm{III})$-terephthalate containing layered double hydroxides. Opt. Mater. 2018, 80, 186-196.

18. Tsaryuk, V.I.; Zhuravlev, K.P.; Zolin, V.F.; Kudryashova, V.A.; Legendziewicz, J.; Szostak, R. Luminescence efficiency of aromatic carboxylates of europium and terbium when methylene bridges and nitro groups are present in the ligands. J. Appl. Spectrosc. 2007, 74, 51-59. [CrossRef] 
19. Hu, X.; Gao, X. Multilayer coating of gold nanorods for combined stability and biocompatibility. Phys. Chem. Chem. Phys. 2011, 13, 10028-10035.

20. Li, C.; Wang, L.; Evans, D.G.; Duan, X. Thermal Evolution and Luminescence Properties of Zn-Al-Layered Double Hydroxides Containing Europium(III) Complexes of Ethylenediaminetetraacetate and Nitrilotriacetate. Ind. Chem. Res. 2009, 48, 2162-2171. [CrossRef]

21. Sohn, Y. Structural and spectroscopic characteristics of terbium. hydroxide/oxide nanorods and plates. Ceram. Int. 2014, 40, 13803. [CrossRef]

22. Jyothy, P.V.; Amrutha, K.A.; Gijo, J.; Unnikrishnan, N.V. Fluorescence enhancement in $\mathrm{Tb}^{3+} / \mathrm{CdS}^{2}$ nanoparticles doped silica xerogels. J. Fluoresc. 2009, 19, 165. [CrossRef] [PubMed]

23. Tran, H.N.; Lin, C.; Woo, S.H.; Chao, H.P. Efficient removal of copper and lead by Mg/Al layered double hydroxides intercalated with organic acid anions: adsorption kinetics, isotherms, and thermodynamics. Appl. Clay Sci. 2018, 154, 17-27. [CrossRef]

24. Li, S.; Qin, H.; Zuo, R.; Bai, Z. Tribological performance of Mg/Al/Ce layered double hydroxides nanoparticles and intercalated products as lubricant additives. Appl. Surf. Sci. 2015, 353, 643-650. [CrossRef]

25. Costa, D.G.; Rocha, A.B.; Souza, W.F.; Chiaro, S.S.; Leita, A.A. Comparative Structural, thermodynamic and electronic analyses of $\mathrm{ZnAlAn}-$ hydrotalcite-like compounds (An - $\mathrm{Cl}-, \mathrm{F}-, \mathrm{Br}-, \mathrm{OH}-, \mathrm{CO} 32-$ or NO3-): An ab initio study. Appl. Clay. Sci. 2012, 56, 16-22. [CrossRef]

26. Serdechnova, M.; Salak, A.N.; Barbosa, F.S.; Vieira, D.E.L.; Tedim, J.; Zheludkevich, M.L.; Ferreira, M.G.S. Interlayer intercalation and arrangement of 2-mercaptobenzothiazolate and 1,2,3 benzotriazolate anions in layered double hydroxides: In situ X-ray diffraction study. J. Solid State Chem. 2016, 233, 158-165. [CrossRef]

27. Smalenskaite, A.; Sen, S.; Salak, A.N.; Ferreira, M.G.S.; Skaudzius, R.; Katelnikovas, A.; Kareiva, A. Sol-gel Synthesis and Characterization of Non-Substituted and Europium-Substituted Layered Double Hydroxides $\mathrm{Mg}_{3 /} \mathrm{Al}_{1-\mathrm{x}} \mathrm{Eu}_{\mathrm{x}}$. Curr. Inorg. Chem. 2016, 6, 149-154. [CrossRef]

28. Gago, S.; Pillinger, M.; Ferreira, R.A.S.; Carlos, L.D.; Santos, T.M.; Goncalves, I.S. Immobilization of lanthanide ions in a pillared layered double hydroxide. Chem. Mater. 2005, 17, 5803-5809. [CrossRef]

29. Yan, B.; Wang, W.-J.; Song, Y.-S. Photophysical properties of praseodymium complexes with aromatic carboxylic acids: double light conversion both in ultraviolet and visible region. Spectrochim. Acta Part A 2007, 66, 1115-1121. [CrossRef] [PubMed]

30. Bryce-Smith, D.; Gilbert, A.; Orger, B.; Twitchett, P. Photoaddition of ethylenes and acetylenes to hexafluorobenzene. Chem. Soc. 1978, 1, 241-245. [CrossRef]

31. Hilder, M.; Junk, P.C.; Kynast, U.H.; Lezhnina, M.M. Spectroscopic properties of lanthanoid benzene carboxylates in the solid state: Part 1. J. Photochem. Photobiol. A 2009, 202, 10-20. [CrossRef]

32. Xu, Z.P.; Braterman, P.S. Synthesis, structure and morphology of organic layered double hydroxide (LDH) hybrids: Comparison between aliphatic anions and their oxygenated analogs. Appl. Clay Sci. 2010, 48, 235-242. [CrossRef]

(C) 2019 by the authors. Licensee MDPI, Basel, Switzerland. This article is an open access article distributed under the terms and conditions of the Creative Commons Attribution (CC BY) license (http://creativecommons.org/licenses/by/4.0/). 